\title{
CHARACTERIZATION OF SUGARS AND ORGANIC ACIDS IN COMMERCIAL VARIETIES OF TABLE GRAPES
}

\author{
Pablo Muñoz-Robredoํㅗ Paula Robledo ${ }^{1}$, Daniel Manríquez ${ }^{1}$, Rosa Molina ${ }^{1}$, \\ and Bruno G. Defilippi ${ }^{1,2 *}$
}

Flavor composition has been defined as a complex attribute of fruit quality, in which the mix of sugars, acids and volatiles play a primary role. In table grapes (Vitis vinifera L.), sweetness and sourness are the most important flavor attributes for fresh consumption. However, most of the studies available have been performed on wine grapes, which are grown, cultured and processed differently to table grapes. Therefore, the objective of this work was to characterize the changes in sugars and organic acids during the development of 'Thompson Seedless', 'Red Globe' and 'Crimson Seedless' grown under the same agroclimatic conditions. Each variety was sampled weekly from 2 wk before véraison until commercial harvest. Sugars and organic acids were quantified by high performance liquid chromatography (HPLC) equipped with an evaporative light scattering detector (ELSD) and ultra violet detector, respectively. The ranges of acid and sugars concentrations found in grapes were as follows: tartaric acid, 1.28-7.45 $\mathrm{g} \mathrm{L}^{-1}$; malic acid, 0.38-29.92 $\mathrm{g} \mathrm{L}^{-1}$, citric acid traces-1.03 $\mathrm{g} \mathrm{L}^{-1}$; fructose, 0.15 $8.74 \mathrm{~g}$ (sugar) $100 \mathrm{~g}(\text { grape })^{-1}$; glucose, 0.19-8.71 g (sugar) $100 \mathrm{~g}$ (grape $)^{-1}$ and sucrose $0.02-0.91 \mathrm{~g}$ (sugar) $100 \mathrm{~g}(\text { grape })^{-1}$. Among sugars, glucose was the most abundant one in early stages and then it decreased until the harvest period, when the amount of fructose and glucose converged to an average of $47 \%$ for each sugar. Despite organic acids reaching steady levels 3-4 wk before commercial harvest, there were important differences in the organic acid profiles among varieties, with 'Thompson Seedless' showing the lowest tartaric/malic acid ratio of 1.19. These differences are an important aspect in terms of overall flavor.

Key words: Fructose, glucose, tartaric acid, malic acid, chromatography, development stages, HPLC, Vitis vinifera.

$\mathrm{T}$ o be successful in the fresh fruit market, table grapes (Vitis vinifera L.) must possess a series of characteristics requested by consumers. The overall flavor is one of the most important qualities for establishing a continuous consumer preference. Flavor composition has been defined as a complex attribute of quality, in which the mix of sugars, acids, and volatiles plays a primary role (Baldwin, 2002). In addition to the four basic flavors (sweet, sour, salty, and bitter) that humans can recognize in fruits and vegetables, aroma has an important influence on the final consumer acceptance of the commodity (Defilippi et al., 2009). Among the flavor metabolites already mentioned, sugar and organic acid compositions, which are measured through total soluble solids (TSS) and titratable acidity (TA), are most commonly associated with the taste of fruits, including table grapes (Ferguson and Boyd, 2002; Shiraishi et al., 2010).

From the consumers' perspective, the organoleptic quality of table grapes depends mainly on the sugar content, organic acid content and the balance between

${ }^{1}$ Instituto de Investigaciones Agropecuarias INIA, P.O. Box 439-3, Santiago, Chile. *Corresponding author (bdefilip@inia.cl).

${ }^{2}$ The Plant Cell Biotechnology Millennium Nucleus, Santiago, Chile. Received: 25 January 2011.

Accepted: 24 June 2011. them. In regard to the sugar content, glucose and fructose are present in similar amounts, while sucrose contributes less than $1 \%$ and the starch concentration is practically negligible (Nelson, 1985; Conde et al., 2007). However, a few high-sucrose content cultivars have been characterized in Vitis rotundifolia and hybrids between V. labrusca and $V$. vinifera (Liu et al., 2006). Organic acids are present in small amounts compared to sugars. However, they contribute significantly to the overall taste (Nelson, 1985). In general, organic acids do not exceed more than $1 \%$ of the total juice weight, with tartaric acid usually the most important acid followed by malic, citric, succinic, and other acids. Generally malic and tartaric acids accumulate before véraison, followed by a strong decline in malic acid content. Tartaric acid shows little change until harvest. However, the ratio of tartaric to malic acid is cultivar-specific and depends on the genetic background. Differences in the acidity of the table grape at harvest can be due to differences between varieties, environmental conditions, storage time, and other factors (Diakou et al., 1997; Navarro et al., 2001; Liu et al., 2006). Despite the importance of TA to the overall flavor, growers mainly use TSS (sweetness) as an indicator of ripeness and most of the commercial varieties are considered mature when TSS ranges from 15 to $18 \%$. Furthermore, the chemical composition of grapes, similar 
to other species, is influenced by several factors such as maturity, genotype and growing conditions (King et al., 1988; Liu et al., 2006).

Most of the available information related to flavor in grapes has been developed for grapes used for wine production. However, the varieties available for fresh consumption have unique characteristics and are subjected to processes that result in a different product from a commercial perspective. Table grape production relies mainly on varieties that are harvested with a lower level of soluble solids than wine grapes, which is sometimes independent of the titratable acidity in red color varieties (Adler et al., 2000; Piva, 2001; Liu et al., 2006). The organoleptic characteristics of the fruit are selected for fresh consumption and several plant growth regulators are applied during fruit development to attain consumer acceptance (Zoffoli et al., 2008). Furthermore, table grapes are stored for long periods before reaching markets.

The main objective of this study was to characterize changes in the composition of sugars and organic acids in table grapes during berry ripening in the most important commercial varieties of table grapes grown in Chile and commercialized worldwide, i.e. 'Thompson Seedless', 'Red Globe', and 'Crimson Seedless'.

\section{MATERIAL AND METHODS}

\section{Plant material}

Table grapes from the commercial varieties Thompson Seedless, Red Globe, and Crimson Seedless were obtained between December 2009 and April 2010 from a commercial orchard located in Los Andes, Region of Valparaiso, Chile. Grapes were sampled weekly starting before véraison ( $7 \mathrm{wk}$ before harvest) until the time of commercial harvest identified by the technical staff of the orchard. For each variety, three clusters were obtained from three homogeneous vines at each sampling time. Due to the important effect of environmental and cultural factors on sugars and organic acids content (Tesic et al., 2002), the samples were collected from vines grown under the same temperature and relative humidity conditions to minimize the effects that environmental conditions can cause (Le Moigne et al., 2008; Rolle et al., 2011). Furthermore, the three varieties were similar in age, rootstock, and training. Plant growth regulators (PGR) are broadly used in table grape production and our aim was to characterize the behavior of the varieties under commercial conditions. In general, gibberellic acid was only used in 'Thompson Seedless' and 'Crimson Seedless' in early stages of fruit development. Furthermore, no PGRs for color development were used. Immediately after sampling, grapes were transported to the laboratory where maturity parameters were measured. For sugars and organic acids, berries were selected randomized per individual cluster and frozen with liquid nitrogen and stored at $-80^{\circ} \mathrm{C}$ until analyses.

\section{Maturity parameters}

The soluble solid content (SSC) was measured with a manual temperature-compensated refractometer (ATC$1 \mathrm{E}$, Atago, Tokyo, Japan) in a sample of juice from fifteen berries collected randomized within each clusters. The results were expressed as a percentage (\%). Titratable acidity was obtained through the titration of $10 \mathrm{~mL}$ juice from a representative sample of the fruits, with $0.1 \mathrm{~N}$ $\mathrm{NaOH}$ until achieving the neutralization of the organic acids to $\mathrm{pH}$ 8.2-8.3. In this case, results were expressed as a percentage of tartaric acid equivalents.

\section{Sugars and organic acid content}

Samples for sugars and organic acids were prepared from a homogenous sample of $60 \mathrm{~g}$ of tissue per cluster or replicate. From the nine cluster collected at harvest, we selected six replicates per variety at each sampling time. This selection was based on TA data collected in each opportunity. Sugars and organic acids were analyzed according to the method of Pérez et al. (1997). Briefly, $10 \mathrm{~g}$ tissue were homogenized in a fruit crusher (Polytron) with $25 \mathrm{~mL}$ of cold $95 \%$ ethanol for 3-5 min. The sample was centrifuged at $12000 \mathrm{rpm}$ for $20 \mathrm{~min}$ and vacuum filtered through two layers of Whatman $\mathrm{N}^{\circ}$ 1 paper. The solution was brought to $50 \mathrm{~mL}$ volume with $80 \%$ ethanol. Then, an aliquot of $10 \mathrm{~mL}$ was dried under a nitrogen stream at $50{ }^{\circ} \mathrm{C}$. The residue was dissolved in $2 \mathrm{~mL}$ of $0.2 \mathrm{~N} \mathrm{H}_{2} \mathrm{SO}_{4}$ with $0.05 \%$ EDTA. The sample was loaded onto an activated Sep-Pak C-18 cartridge and the eluate collected. The sample was washed thoroughly with an additional $4 \mathrm{~mL}$ of the solution. The eluate was filtered through a $0.45 \mu \mathrm{m}$ filter and analyzed by HPLC.

For quantification, calibration curves were designed based on standards for each compound. Calibration curves for D-(-) fructose (Sigma-Aldrich, St. Louis, Missouri, USA), D-(+) glucose and sucrose (Supelco Analytical, Bellefonte, Pennsylvania, USA) were used to quantify the sugars, while calibration curves for citric acid, D-malic acid, ascorbic acid (Supelco Analytical) and D-(-)-tartaric acid (Fluka, Buchs, Switzerland) were used to quantify the acids.

Sugars were analyzed in a chromatograph composed of an Evaporative Light Scattering Detector (ELSD) detector, Sedex 60 lt ELSD (Sedere) and an interface LCNET II/ADC (JASCO, Japan). The separation of sugars was performed using an amino column Kromasil 100 $5 \mathrm{NH}_{2}(250 \mathrm{~mm} \times 4.6 \mathrm{~mm})($ AkzoNobel, Bohus, Sweden) with a mobile phase of $77 \%$ acetonitrile and $23 \%$ HPLC grade water, degassed and ultrasonicated. The analysis conditions were held constant at a flow rate of $1.8 \mathrm{~mL}$ $\min ^{-1}$ for $9 \mathrm{~min}$ at $20{ }^{\circ} \mathrm{C}$ under a pressure of $13.2 \mathrm{kPa}$. The injection volume was $20 \mu \mathrm{L}$.

Organic acids were analyzed in a chromatograph with an ultra-violet detector L-4250A UV-VIS (MerckHitachi, Tokio, Japan) selected at $195 \mathrm{~nm}$ with the 
interface D-6000 (Merck-Hitachi). The separation of acids was performed using a Symmetry C-18 (4.6 mm $\times 250 \mathrm{~mm}, 5.0 \mu \mathrm{m}$ ) (Waters, Wexford, Ireland). The data were analyzed using D-7000 HSM software. The mobile phase used was $0.0085 \mathrm{~N} \mathrm{H}_{2} \mathrm{SO}_{4}$ degassed and ultrasonicated and the analysis conditions were held constant at a flow rate of $0.4 \mathrm{~mL} \mathrm{~min}^{-1}$ for $24 \mathrm{~min}$ at $20{ }^{\circ} \mathrm{C}$, at an average pressure of $8.4 \mathrm{kPa}$. The injection volume was $20 \mu \mathrm{L}$.

\section{Statistical analysis}

Each variety was analyzed as a single assay. As mentioned above, data reported are means of at least six replicates. ANOVA and comparisons between means were made with Tukey tests at $\mathrm{p} \leq 0.05$ using Statgraphics Plus 5.1 (Manugistics Inc., Rockville, Maryland, USA).

\section{RESULTS AND DISCUSSION}

Total soluble solids (TSS) showed the largest increase between 7 and 4 wk before commercial harvest for all three varieties studied (Figure 1). 'Red Globe' and 'Crimson Seedless' showed the largest change in TSS (close to $13 \%$ TSS) and a continuous rise throughout the sampling period. However, 'Thompson Seedless' reached a plateau from $4 \mathrm{wk}$ prior to harvest to the end of the sampling period. A reduction in titratable acidity (TA) close to $4 \%$ was observed during berry development in the three varieties. 'Red Globe' was the variety showing the largest decline ( $\Delta=-4.0 \%$ of acidity), while 'Crimson Seedless' was the variety with the smallest drop in TA ( $\Delta=-2.6 \%$ of acidity). From 4 wk before harvest $(\mathrm{H}-$ 4 ), the TA levels remained constant in the three varieties studied. These results indicate that if TSS increases and TA decreases as berry development progresses, then the ratio between these values increases over time (Figure 1). According to Crisosto (2002), commercial harvest of table grapes is reached when the quotient TSS/TA has a value close to 20 . This value has been defined as the lowest one for consumer preference (Jayasena and Cameron, 2009). Du Plessis (1977) suggested that the TSS/TA ratio is a good indicator of grape ripeness due to the changes in the concentration of sugars and organic acids from one year to another under similar conditions. In this study, the value was reached in 'Red Globe' between 4 and 3 wk before the commercial harvest ( $\mathrm{H}-4$ and $\mathrm{H}-3$, respectively). However, the harvest was performed when the berry obtained the optimum red color requested by the consumers. For 'Crimson Seedless' and 'Thompson Seedless', this quotient was reached $1 \mathrm{wk}$ prior to harvest. These results indicate the need to revise the maturity index through berry development for individual varieties according to the quality attributes considered for consumption and commercialization. Because TSS and TA levels showed no significant changes from $2 \mathrm{wk}$ before harvest, we did not include the measurements
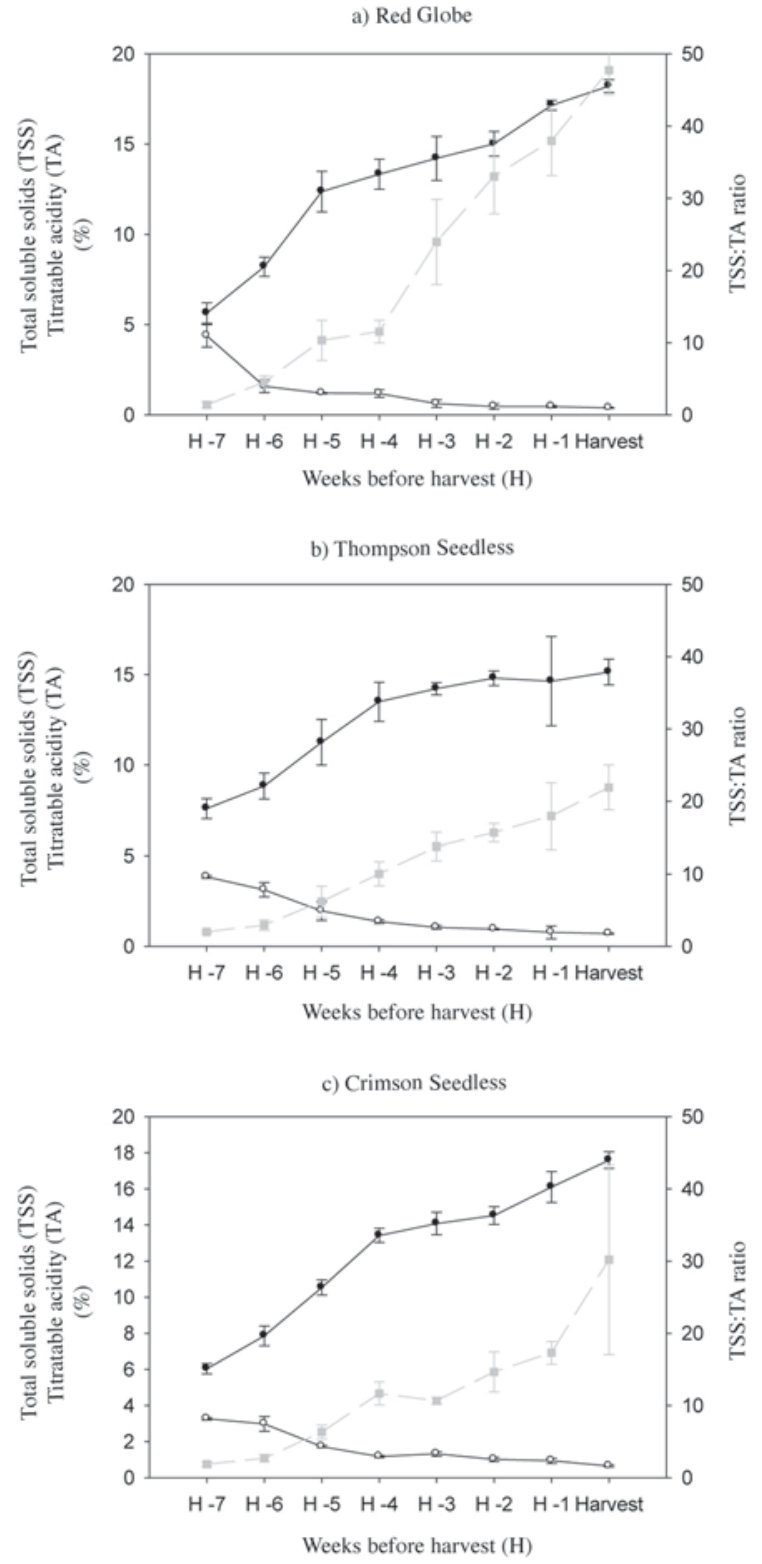

- Solublo Solid $\longrightarrow$ Titratable Acidity $\cdots$ Ratio S.S vis T.A

Figure 1. Total soluble solids $(\%)$, titratable acidity (\% of tartaric acid equivalents) and their ratio for 'Red Globe', 'Thompson Seedless' and 'Crimson Seedless' table grapes.

for sugars and organic acids from this point forward. As mentioned above, some PGRs could modify the chemical and physical characteristics of the berry. However, based on the PGRs used on the varieties in this study, no major differences are expected without their presence (Sato et al., 2004; Peppi et al., 2006; Rolle et al., 2011).

Glucose was the most abundant sugar in early stages, close to véraison. Glucose then decreased until the harvest period, when the amount of fructose and glucose converged to an average of $47 \%$ for each sugar (Figure 2). Generally, no major differences were observed between 
fructose and glucose from 6-5 wk prior to harvest in terms of concentration (Table 1) and contribution to total sugars (Figure 2). The sucrose concentration was low in all three varieties, never exceeding $5 \%$ of total sugars (Table 1). These results are similar to the observations made by Kliewer (1965) and recent work on wine grapes. At harvest, the total sugars account for more than $90 \%$ of
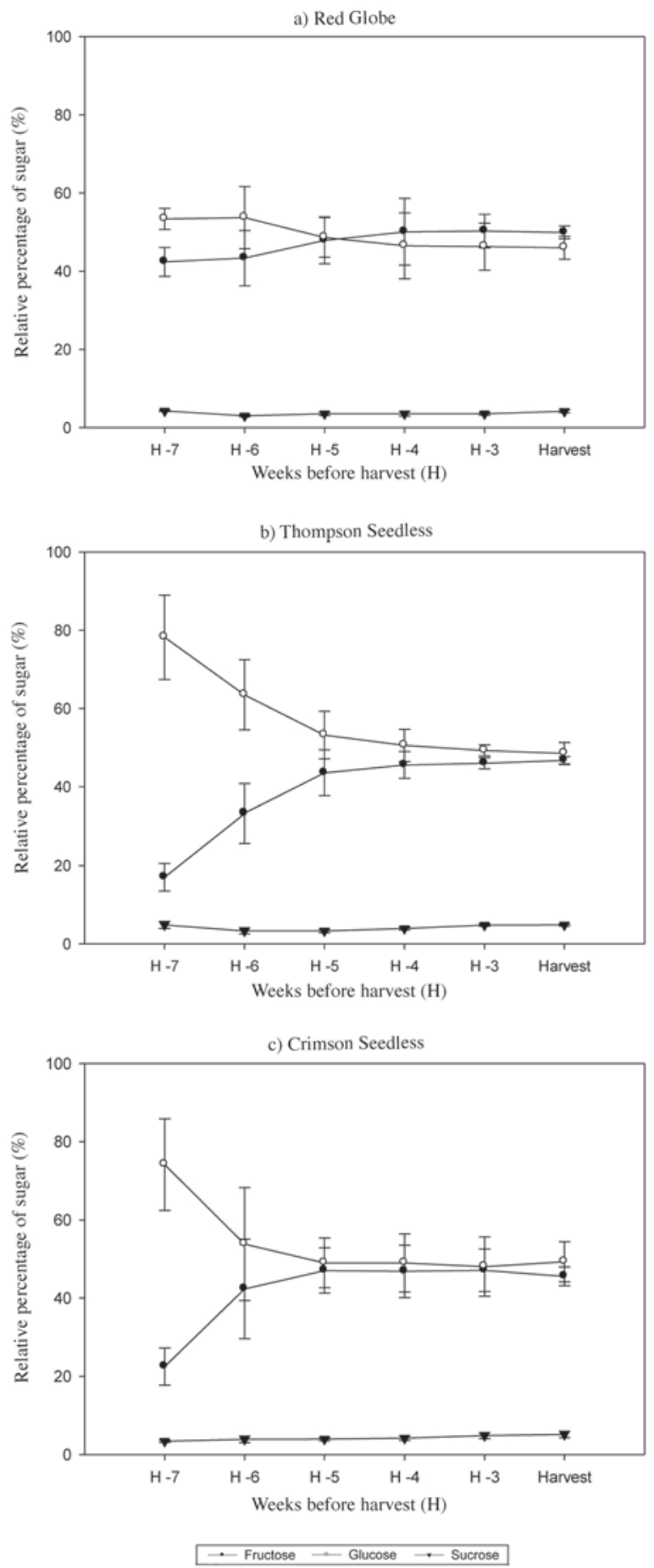

Figure 2. Relative composition of individual sugars (glucose, fructose, and sucrose) relative to total sugar in table grapes during berry development.
Table 1. Amount of sugars ( $\mathrm{g}$ sugars $100 \mathrm{~g}^{-1}$ grape) of 'Red Globe', 'Thompson Seedless' and 'Crimson Seedless' table grapes throughout berry development.

\begin{tabular}{llllllr}
\hline & \multicolumn{5}{c}{ Sampling time in days relative to harvest (H) } \\
\cline { 2 - 7 } Compound & $\mathrm{H}-7$ & $\mathrm{H}-6$ & $\mathrm{H}-5$ & $\mathrm{H}-4$ & $\mathrm{H}-3$ & Harvest \\
\cline { 2 - 7 } Red Globe & & \multicolumn{7}{c}{ g sugars $100 \mathrm{~g} \mathrm{~g}^{-1}$ grape } \\
Fructose & $0.15 \mathrm{e}$ & $1.97 \mathrm{~d}$ & $3.97 \mathrm{c}$ & $4.33 \mathrm{c}$ & $6.80 \mathrm{~b}$ & $8.74 \mathrm{a}$ \\
Glucose & $0.19 \mathrm{e}$ & $2.44 \mathrm{~d}$ & $4.03 \mathrm{c}$ & $4.02 \mathrm{c}$ & $6.26 \mathrm{~b}$ & $8.06 \mathrm{a}$ \\
Sucrose & $0.02 \mathrm{e}$ & $0.14 \mathrm{~d}$ & $0.29 \mathrm{c}$ & $0.30 \mathrm{c}$ & $0.47 \mathrm{~b}$ & $0.73 \mathrm{a}$ \\
Total sugars & 0.35 & 4.54 & 8.29 & 8.66 & 13.53 & 17.54 \\
Thompson Seedless & & & & & & \\
Fructose & $0.57 \mathrm{~d}$ & $3.35 \mathrm{c}$ & $4.88 \mathrm{bc}$ & $5.14 \mathrm{bc}$ & $7.10 \mathrm{ab}$ & $8.05 \mathrm{a}$ \\
Glucose & $1.87 \mathrm{~d}$ & $4.26 \mathrm{c}$ & $5.08 \mathrm{bc}$ & $5.37 \mathrm{bc}$ & $7.24 \mathrm{~b}$ & $8.71 \mathrm{a}$ \\
Sucrose & $0.09 \mathrm{c}$ & $0.31 \mathrm{c}$ & $0.41 \mathrm{~b}$ & $0.46 \mathrm{~b}$ & $0.73 \mathrm{ab}$ & $0.91 \mathrm{a}$ \\
Total sugars & 2.52 & 7.91 & 10.37 & 10.97 & 15.07 & 17.67 \\
Crimson Seedless & & & & & & \\
Fructose & $0.26 \mathrm{e}$ & $1.69 \mathrm{~d}$ & $3.57 \mathrm{c}$ & $5.46 \mathrm{~b}$ & $5.53 \mathrm{~b}$ & $7.74 \mathrm{a}$ \\
Glucose & $1.21 \mathrm{e}$ & $3.23 \mathrm{~d}$ & $4.36 \mathrm{c}$ & $6.06 \mathrm{~b}$ & $5.93 \mathrm{~b}$ & $8.03 \mathrm{a}$ \\
Sucrose & $0.07 \mathrm{~d}$ & $0.17 \mathrm{~cd}$ & $0.27 \mathrm{c}$ & $0.47 \mathrm{~b}$ & $0.57 \mathrm{~b}$ & $0.80 \mathrm{a}$ \\
Total sugars & 1.54 & 5.09 & 8.20 & 11.99 & 12.03 & 16.57 \\
\hline
\end{tabular}

Different letters show statistical differences $(\mathrm{P}<0.05)$ among sampling times within individual sugars.

TSS, measured by a refractometer. This result confirms the importance of using this parameter as a sugar content indicator and a harvesting index (Shiraishi et al., 2010). However, our results suggest that in earlier stages of development (H-4 or earlier), there are other soluble compounds, such as organic acids, that affect the TSS.

Based on the knowledge gained from the composition of sugars in the different varieties and on the definition of sweetness given by the sweetening power of sucrose, a theoretical analysis of sweetness was performed. This value was determined using a solution of $30 \mathrm{~g} \mathrm{~L}^{-1}$ sucrose at $20{ }^{\circ} \mathrm{C}$, which was assigned a base sweetness power equal to 100 units. Within this scale, it is generally accepted that the sweetness of fructose has a value of 173, while glucose has a value of only 74 units (Godshall, 1988). Based on this analysis, a relative sweetness value was given for each variety studied (Figure 3 ). The results from this analysis, combined with the levels of the single sugars measured in the varieties studied, indicated that the largest sugar contributing to the sweetness of table grapes during the sampling period was fructose, followed by glucose and sucrose. This predominance of fructose in the sweetness measurement could be due to the index strongly weighting fructose even though it is at the same concentration as glucose in our study. The fructose contribution exceeds that of sucrose by $73 \%$ and that of glucose by over $200 \%$. As mentioned above, the rest of the sweetness is mainly attributed to glucose as a result of the high concentration (Figure 3). All three varieties studied showed a similar behavior in the contribution of sugars to the overall sweetness throughout the progress of berry development. Thus, our results show that the differences in sweetness for each table grape variety depends more on the amount of total sugars present in the variety rather than the proportion of sugars present in the berry.

The organic acid profile changed during berry development and it was observed that the major changes 

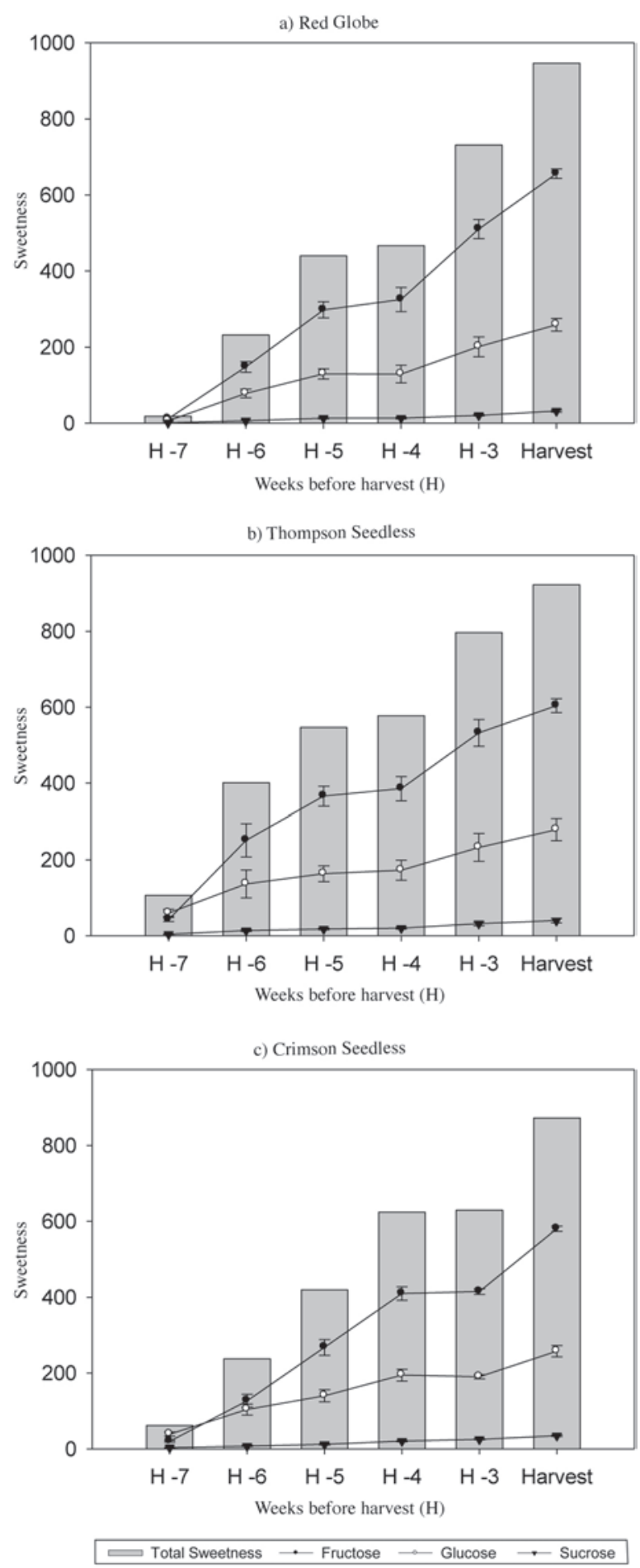

Figure 3. Contribution of individual sugars (solid lines) and the total composition of sweetness that was present in the grape (solid bars) in units of sweetness. Units of sweetness were calculated using the base sweetness power of the sucrose as a reference of sweetness.

occurred close to the veraison stage (between H-6 and $\mathrm{H}-5)$. This finding was confirmed by the change of color development for 'Red Globe' and 'Crimson Seedless' and, in particular, by the increase in ethylene biosynthesis detected in the three varieties studied (data not shown) (Chervin et al., 2004).

As expected for organic acids in grapes, malic acid was predominant close to véraison $(\mathrm{H}-6)$ followed by tartaric acid and citric acid (Table 2). Furthermore, malic acid accounted for more than $50 \%$ of the total acids until $4 \mathrm{wk}$ before harvest in the three varieties studied (Figure 4). From approximately $3 \mathrm{wk}$ before harvest, tartaric acid dominated and accounted for 60 $80 \%$ of the total acids at harvest time. These changes are caused by the degradation of malic acid (Philip and Nelson, 1973; Ruffner and Hawker, 1977; De Bolt et al., 2006). Tartaric acid showed a smaller decline due to the increase in berry volume and not due to consumption or degradation (Ruffner, 1982). At harvest time, 'Thompson Seedless' was the variety with the lowest tartaric/malic acid ratio. However, 'Crimson Seedless' and 'Red Globe' both showed a greater difference in the content of both acids. Furthermore, citric acid was also present in 'Red Globe' but at much lower levels than malic and tartaric acids.

Unlike the results observed for sugars, the relationship between acids in each variety varies significantly and reinforces the hypothesis that the composition of acids in grape is a key component that could be related to differences in flavor for each variety (Adler et al., 2000; Liu et al., 2006). These changes are an important issue in terms of flavor if only TA is considered as an indicator and is especially true in varieties where there are little changes in the TA value but significant changes in organic acid composition, as observed for 'Red Globe' in our study. It is well known that organic acids contribute to the sourness of a fruit, while tartaric acid has a more important role in determining both concentration and palatable acidity (Liu et al., 2006). Therefore, differences in flavor should be addressed when determining an appropriate harvest time for each individual variety.

Table 2. Amount of organic acids $\left(\mathrm{g} \mathrm{L}^{-1}\right)$ for 'Red Globe', 'Thompson Seedless' and 'Crimson Seedless' table grapes throughout berry development.

\begin{tabular}{|c|c|c|c|c|c|c|}
\hline \multirow[b]{2}{*}{ Compound } & \multicolumn{6}{|c|}{ Sampling time in days relative to harvest $\mathrm{H}$} \\
\hline & $\mathrm{H}-7$ & $\mathrm{H}-6$ & $\mathrm{H}-5$ & $\mathrm{H}-4$ & $\mathrm{H}-3$ & Harvest \\
\hline & \multicolumn{6}{|c|}{$\mathrm{g} \mathrm{L}^{-1}$} \\
\hline \multicolumn{7}{|l|}{ Red Globe } \\
\hline Tartaric acid & $6.68 \mathrm{a}$ & $4.62 b$ & $3.08 \mathrm{c}$ & $2.31 \mathrm{~cd}$ & $2.05 \mathrm{~d}$ & $1.28 \mathrm{~d}$ \\
\hline Malic acid & $24.78 \mathrm{a}$ & $12.20 \mathrm{~b}$ & $8.22 \mathrm{c}$ & $2.05 \mathrm{~d}$ & $0.77 \mathrm{~d}$ & $0.39 \mathrm{~d}$ \\
\hline Citric acid & $1.03 \mathrm{a}$ & $0.77 \mathrm{ab}$ & $1.03 \mathrm{a}$ & $0.51 \mathrm{ab}$ & $0.26 \mathrm{~b}$ & $0.25 \mathrm{~b}$ \\
\hline Total acids & 32.49 & 17.59 & 12.33 & 4.75 & 3.21 & 1.93 \\
\hline \multicolumn{7}{|c|}{ Thompson Seedless } \\
\hline Tartaric acid & $6.55 \mathrm{a}$ & $4.62 b$ & $2.18 \mathrm{c}$ & $1.54 \mathrm{c}$ & $2.44 \mathrm{c}$ & $2.05 \mathrm{c}$ \\
\hline Malic acid & $29.92 \mathrm{a}$ & $25.94 \mathrm{a}$ & $10.14 b$ & $6.29 \mathrm{c}$ & $1.16 \mathrm{~d}$ & $1.80 \mathrm{~d}$ \\
\hline Citric acid & $0.40 \mathrm{a}$ & $0.39 \mathrm{a}$ & $0.13 b$ & $0.03 \mathrm{~b}$ & $0.01 b$ & $\mathrm{~N} / \mathrm{D}^{1}$ \\
\hline Total acids & 36.86 & 30.94 & 12.33 & 7.83 & 3.60 & 3.85 \\
\hline \multicolumn{7}{|c|}{ Crimson Seedless } \\
\hline Tartaric acid & $7.45 \mathrm{a}$ & $7.58 \mathrm{a}$ & $3.85 \mathrm{~b}$ & $2.57 \mathrm{c}$ & $2.31 \mathrm{c}$ & $1.80 \mathrm{c}$ \\
\hline Malic acid & $25.04 \mathrm{~b}$ & $29.40 \mathrm{a}$ & $7.70 \mathrm{c}$ & $2.97 \mathrm{~d}$ & $2.95 \mathrm{~d}$ & $0.51 \mathrm{e}$ \\
\hline Citric acid & $0.13 \mathrm{a}$ & $0.13 \mathrm{a}$ & traces & traces & traces & $\mathrm{N} / \mathrm{D}^{1}$ \\
\hline Total acids & 32.74 & 37.11 & 11.56 & 5.53 & 5.26 & 2.31 \\
\hline
\end{tabular}



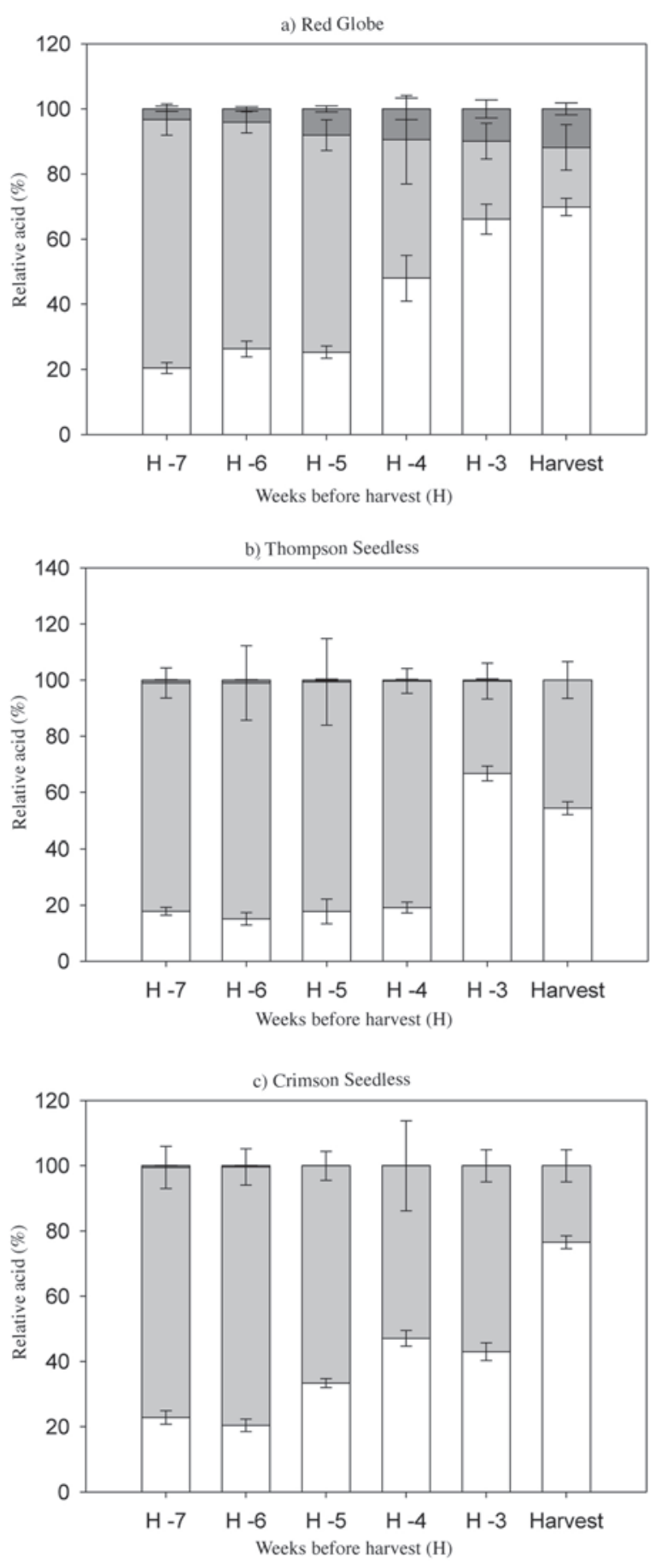

$\Longleftarrow$ Citric Acid $\rightleftharpoons$ Malic Acid $\rightleftharpoons$ Tartaric Acid

Figure 4. Percent relative composition of organic acids present in the different grape varieties throughout the sampling period.

The results from the varieties 'Thompson Seedless', 'Crimson Seedless' and 'Red Globe' show that it is not appropriate to use a single attribute for all table grape varieties to determine commercial harvesting. One example is total soluble solids, which showed important differences in individual sugars and organic acids from the early stages of berry development between the three varieties studied. These differences could significantly affect the overall flavor. This finding is especially relevant when other attributes, such as the development of external color in red color varieties is considered. For the three varieties studied, the total amount of sugars impacted the sweetness more than the relative amount of individual sugars. Similar results were observed for other varieties not reported in this work (e.g., 'Flame Seedless' and 'Superior Seedless'). However, it could be different in varieties with high sucrose content (Liu et al., 2006). Similar results could be expected in varieties with a different profile of organic acids, such as that observed for 'Red Globe' in this study. This variety had a higher content of citric acid. Based on consumer's preference, further research should also be performed to study the role of volatile metabolites in the development of overall flavor in the varieties studied.

\section{CONCLUSIONS}

Based on the results from this study, as well as recently published studies on fruit flavor, there is a clear need to understand and examine the changes in metabolites and the underlying biochemical mechanisms determining overall flavor. From this study, we can conclude that the most important differences among the varieties studied were given in terms of the relative amount of the individual compounds determining sweetness and sourness. Moreover a differential rate of sugars and organic acids accumulation/depletion was observed among varieties. Both aspects would have a major incidence in determining overall flavor, being more relevant than the total amount of compounds measured at harvest.

\section{ACKNOWLEDGEMENTS}

This study was funded by project "Understanding changes in overall flavor and its mechanisms of regulation during fruit development and postharvest life of table grapes" (FONDECYT 1100273). We thank Eduardo Torres (INIALa Platina) and Horacio Parra (Agrícola Brown Ltda.) for assistance with field technical support. Corresponding author belongs to The Plant Cell Biotechnology Millennium Nucleus (Santiago, Chile).

Caracterización de azúcares y ácidos orgánicos en variedades comerciales de uva de mesa. La composición del sabor ha sido definida como un atributo complejo de la calidad de la fruta, en el cual la mezcla de azúcares, ácidos y volátiles juega un rol determinante. En uva de mesa (Vitis vinifera L.), el dulzor y la acidez son los atributos primordiales para su consumo fresco. Sin embargo, la mayoría de los estudios realizados al respecto se han desarrollado en uva para la producción de vino, la cual crece, se cultiva y se procesa de manera diferente a la uva 
de mesa. Por lo tanto, el objetivo del presente trabajo se centró en caracterizar los cambios en azúcares y ácidos orgánicos a lo largo de su desarrollo en las variedades 'Thompson Seedless', 'Red Globe', y 'Crimson Seedless', producidas bajo las mismas condiciones agroclimáticas Para cada variedad se realizaron muestreos semanales desde 2 semanas previas a pinta hasta la cosecha comercial. Los azúcares y ácidos orgánicos fueron cuantificados mediante cromatografía líquida de alto rendimiento (HPLC) equipados con detectores evaporativos de dispersión de la luz (ELSD) y ultra violeta, respectivamente. El rango de concentraciones de ácidos y azúcares encontrados en uva fueron los siguientes: ácido tartárico, 1,28-7,45 g L $\mathrm{g}^{-1}$; ácido málico, 0,38-29,92 $\mathrm{g} \mathrm{L}^{-1}$, ácido cítrico trazas-1,03 g $\mathrm{L}^{-1}$; fructosa, 0,15-8,74 g (azúcar) $100 \mathrm{~g}$ (uva) ${ }^{-1}$; glucosa, 0,19-8,71 g (azúcar) $100 \mathrm{~g}$ (uva) ${ }^{-1}$ and sacarosa 0,02-0,91 g (azúcar) $100 \mathrm{~g}$ (uva) ${ }^{-1}$. Entre los azúcares, glucosa fue la más abundante en etapas tempranas y luego disminuyó hasta el período de cosecha, cuando la cantidad de fructosa y glucosa converge en un promedio de $47 \%$ para cada azúcar. A pesar de que los ácidos orgánicos alcanzaron un nivel constante entre 3 a 4 semanas antes de su cosecha, existen diferencias importantes en el perfil de ácidos orgánicos entre las variedades, con 'Thompson Seedless' mostrando la más baja relación de ácidos tartárico/málico de 1,19. Estas diferencias son un punto importante al considerar el sabor general para cada variedad.

Palabras clave: Fructosa, glucosa, ácido tartárico, ácido málico, cromatografía, etapas de desarrollo, HPLC, Vitis vinifera.

\section{LITERATURE CITED}

Adler, E., M.A. Hoon, K.L. Mueller, J. Chandrashekar, N.J. Ryba, and C.S. Zuker. 2000. A novel family of mammalian taste receptors. Cell 100:693-702.

Baldwin, E.A. 2002. Fruit flavor, volatile metabolism and consumer perceptions. p. 89-106. In Knee, M. (ed.) Fruit quality and its biological basis. Sheffield Academic Press, Sheffield, UK.

Chervin, C., A. El-Kereamy, J.P. Roustan, A. Latché, J. Lamon, and M. Bouzayen. 2004. Ethylene seems required for the ripening of grape, a non-climacteric fruit. Plant Science 167:1301-1305.

Conde, C., P. Silva, N. Fontes, A.C.P. Dias, R.M. Tavares, M.J. Sousa, et al. 2007. Biochemical changes throughout grape berry development and fruit and wine quality. Food 1:1-22.

Crisosto, H. 2002. Nuove tecnologie per ridurre i danni da Botryis cinerea nella conservazione dell' uva da tavola. Rivista di Frutticoltura e di Ortofloricoltura 64:30-32.

De Bolt, S., D.R. Cook, and C.M. Ford. 2006. L-Tartaric acid synthesis from vitamin $\mathrm{C}$ in higher plants. Proceedings of the National Academy of Sciences of the United States of America 103:5608-5613.

Defilippi, B.G., D. Manríquez, K. Luengwilai, and M. GonzálezAgüero. 2009. Aroma volatiles: biosynthesis and mechanisms of modulation during fruit ripening. Advances in Botanical Research 50:1-37.

Diakou, P., A. Moing, L. Svanella, N. Ollat, D.B. Rolin, M. Gaudillere, and J.P. Gaudillere. 1997. Biochemical comparison of two varieties differing in juice acidity. Australian Journal of Grape and Wine Research 3:1-10.

Du Plessis, C.S. 1977. Grape components in relation to white wine quality. p. 117-128. Proceedings of the International Symposium in the Quality of the Vintage, Cape Town, South Africa. 14-21 February.

Ferguson, I.B., and L.M. Boyd. 2002. Inorganic nutrients and fruit quality. p. 14-45. In Knee, M. (ed.) Fruit quality and its biological basis. Sheffield Academic Press, Sheffield, UK

Godshall, M.A. 1988. The role of carbohydrates in flavor development. Food Technology 42:71-78.

Jayasena, V., and I. Cameron. 2009. The effect of ethephon and clone on physical characteristics and sensory quality of Crimson Seedless table grapes after 1 month storage. International Journal of Food Science and Technology 44:409-414.

King, R.C., C.A. Sims, L.F. Moore, and R.P. Bates. 1988. Effects of maturity, skin contact and carbonation on the quality of sterile filtered white Muscadine grape juice. Journal of Food Science 53:1474-1485.

Kliewer, W.M., 1965. Changes in the concentration of malates, tartrates, and total free acids in flowers and berries of Vitis vinifera. American Journal of Enology and Viticulture 16:92-100.

Le Moigne, M., C. Maury, D. Bertrand, and F. Jourjon. 2008 Sensory and instrumental characterisation of Cabernet Franc grapes according to ripening stages and growing location. Food Quality and Preference 19:220-231.

Liu, H.F., B.H. Wu, P.G. Fan, S.H. Li, and L.S. Li. 2006. Sugar and acid concentrations in 98 grape cultivars analyzed by principal component analysis. Journal of the Science of Food and Agriculture 86:1526-1536.

Navarro, M., J. Retamales, y B. Defilippi. 2001. Efecto del arreglo de racimo y aplicación de CPPU en la calidad de uva de mesa Sultanina tratada con dos fuentes de giberelinas. Agricultura Técnica 61:15-21.

Nelson, K.E. 1985. Harvesting and handling California table grapes for market. Bulletin 1913. 72 p. University of California Press, DANR Publications, Oakland, California, USA.

Peppi, M.C., M.W. Fidelibus, and N. Dokoozlian. 2006. Abscisic acid application timing and concentration affect firmness, pigmentation, and color of 'flame seedless' grapes. HortScience 41:1440-1445.

Pérez, A.G., R. Olías, J. Espada, J.M. Olías, and C. Sanz. 1997. Rapid determination of sugars, nonvolatile acids, and ascorbic acid in strawberry and other fruits. Journal of Agricultural and Food Chemistry 45:3545-3549.

Philip, T., and F.E. Nelson. 1973. A procedure for quantitative estimation of malic acid and tartaric acids of grape juices. Journal Food and Science 38:18-20.

Piva, C.R. 2001. Modelo de evaluación de la Calidad y de las Preferencias del Consumidor para la uva de mesa. Thesis (Doctorate in Agrarian Economy). Universidad Politécnica de Madrid, Madrid, España.

Rolle, L., S. Giacosa, V. Gerbi, and V. Novello. 2011. Comparative study of texture properties, color characteristics, and chemical composition of ten white table grape varieties. American Journal of Enology and Viticulture 62:49-56.

Ruffner, H.P., and J.S. Hawker. 1977. Control of glycolisis in ripening berries of Vitis vinifera L. Phytochemistry 16:1171-1175.

Ruffner, H.P. 1982. Metabolism of tartaric and malic acids in Vitis: A review-Part A. Vitis 21:346-358.

Sato, A., M. Yamada, H. Iwanami, and M. Mitani. 2004. Quantitative and instrumental measurements of grape flesh texture as affected by gibberellic acid application. Journal of the Japanese Society for Horticultural Science 73:7-11.

Shiraishi, M., H. Fujishima, and H. Chijiwa. 2010. Evaluation of table grape genetic resources for sugar, organic acid, and amino acid composition of berries. Euphytica 174:1-13.

Tesic, D., D. Woolley, E. Hewett, and D. Martin. 2002. Environmental effects on cv. Cabernet Sauvignon (Vitis vinifera L.) grown in Hawke's Bay, New Zealand. 2. Development of a site index. Australian Journal of Grape and Wine Research 8:27-35.

Zoffoli, J.P., B. Latorre, and P. Naranjo. 2008. Preharvest applications of growth regulators and their effect on postharvest quality of table grapes during cold storage. Postharvest Biology and Technology 51:183-192. 